\title{
LEVEL OF LANDSLIDE SUSCEPTIBILITY IN CIBAL DISTRICT OF MANGGARAI EAST NUSA TENGGARA
}

\author{
Dominikus Victorius Bate ${ }^{1}$, Puguh Karyanto ${ }^{2}$, Moh.Gamal Rindarjono ${ }^{3}$ \\ ${ }^{1,2,3}$ Sebelas Maret University, Indonesia \\ Email : dominikusbate04@gmail.com
}

Received: 6 July 2018/Revised: 19 July 2018/Accepted: 30 July 2018/Published online: 28 August 2018

\begin{abstract}
This research aims to determine the degree of susceptibility of landslides in Cibal Districts. The method used in this research is descriptive survey method. The population in this research is all of the land in Cibal Districts. data collection technique is done by using observation technique and documentation study. Data analysis technique in this research uses crosstab technique. The results of this study can be seen that the level of susceptibility of landslides in Cibal based on crosstab results, there are three categories of vulnerability of landslide, they are low, medium and high. Low landslide susceptibility rate of $6.979,65$ hectares or $64,09 \%$ is found in Nine sub-districts / village. The moderate landslide susceptibility rate has an area of $3.634,67$ hectares or $33,38 \%$, in seven villages. While the high landslide susceptibility rate is found only in one village with an area of 275,65 hectares or $2,35 \%$ of the total area of Cibal districts.
\end{abstract}

Keywords : Susceptibility, Landslide, Cibal District

\section{Introduction}

Natural disasters are disasters that caused by events or events that is caused by nature such as earthquakes, tsu-nami, eruption volcanoes, floods, dry, hurricanes, and landslides. Natural disasters can give effects on the economic, social and environmental sectors.

Suripin (2002) defines landslides as a form of erosion where the transport or movement of the soil mass occurs at some point in a relatively big volume. In terms of movement, there are some erosion caused by the movement of the soil mass, creep, rock fall and mud flow. The mass that moves in the landslide is a big mass. Therefore, the occurrance of landslide will bring victims, such as environmental damage, agricultural land, settlement and infrastructure and property and even loss of human life.

According to Minister of Public Works Regulation No. 22 of 2007, the process of landslide that starts from the absorption of rain water into the soil that will increase the weight of soil. If the water penetrates to the impermeable soil that acts as a slip plane, the soil 
becomes slippery and the weathering soil above. It will move along the slope and out the slope. Landslide can occur if the intensity of rainfall is high, slope to steep slopes, thick weathering, rocks and geologic structure varies. Land use is less suitable with the characteristics of the land (Sutikno, 1994 in Permata, 2016).

Susceptibility is a condition caused by human activities (the result of physical, social, and environmental processes) that causes the increasing Susceptibility of society to harm. The degree of vulnerability can be assessed from physical (infrastructure), social, demographic and economic susceptibility (Muta'ali, 2012). Susceptibility is the degree which society, structure, service or geographic area potentially or may be damaged or disturbed by a certain dangerous impact due to its nature, its construction, and its proximity to dangerous or vulnerable areas (Djaelani, 2008).

Susceptibility is a condition of a community group that leads or causes inability to face the threat of danger (Nurjanah, 2011: 16). According to the Regulation of the Head of National Disaster Management Agency (BNPB) No. 04 of 2008 Susceptibility is a state or behavior of people or society that causes inability to face threats or danger.

Cibal is one of the areas that often occur landslide . Recorded on March 3, 2007 occured a great landslide that cause 44 people died, 21 people were injured, 6 houses severely damaged, 500 people evacuated, along the road. There are 5 major landslide point, 14 medium landslide and 12 small landslide and total broke road. In 2016, there were 13 landslide occur in Cibal sub-district which resulted in 14 damaged houses and also many people who suffered injuries. Then, there were 11 major landslides and 4 moderate landslides (BPBD Manggarai Regency, 2007, 2016)

\section{The Methods}

The location of this research is in Cibal District of Manggarai Regency East Nusa Tenggara which is astronomically located between $8^{0} 22^{\prime} 52^{\prime}$ '- $8^{0} 32^{\prime} 50$ " LS and $120^{0} 29^{\prime} 13^{\prime}$ '- $120^{\circ} 30^{\prime} 48$ "BT and based on coordinates Universal Transfer Mercator (UTM) is located between $13396556 \mathrm{mT}-13400525 \mathrm{mT}$ and $932037 \mathrm{mU}$ - $950452 \mathrm{mU}$. The research was conducted from June to August 2017. The area has 17 villages, an area of 10.889,97 hectares and the population is 27.482 soul. 


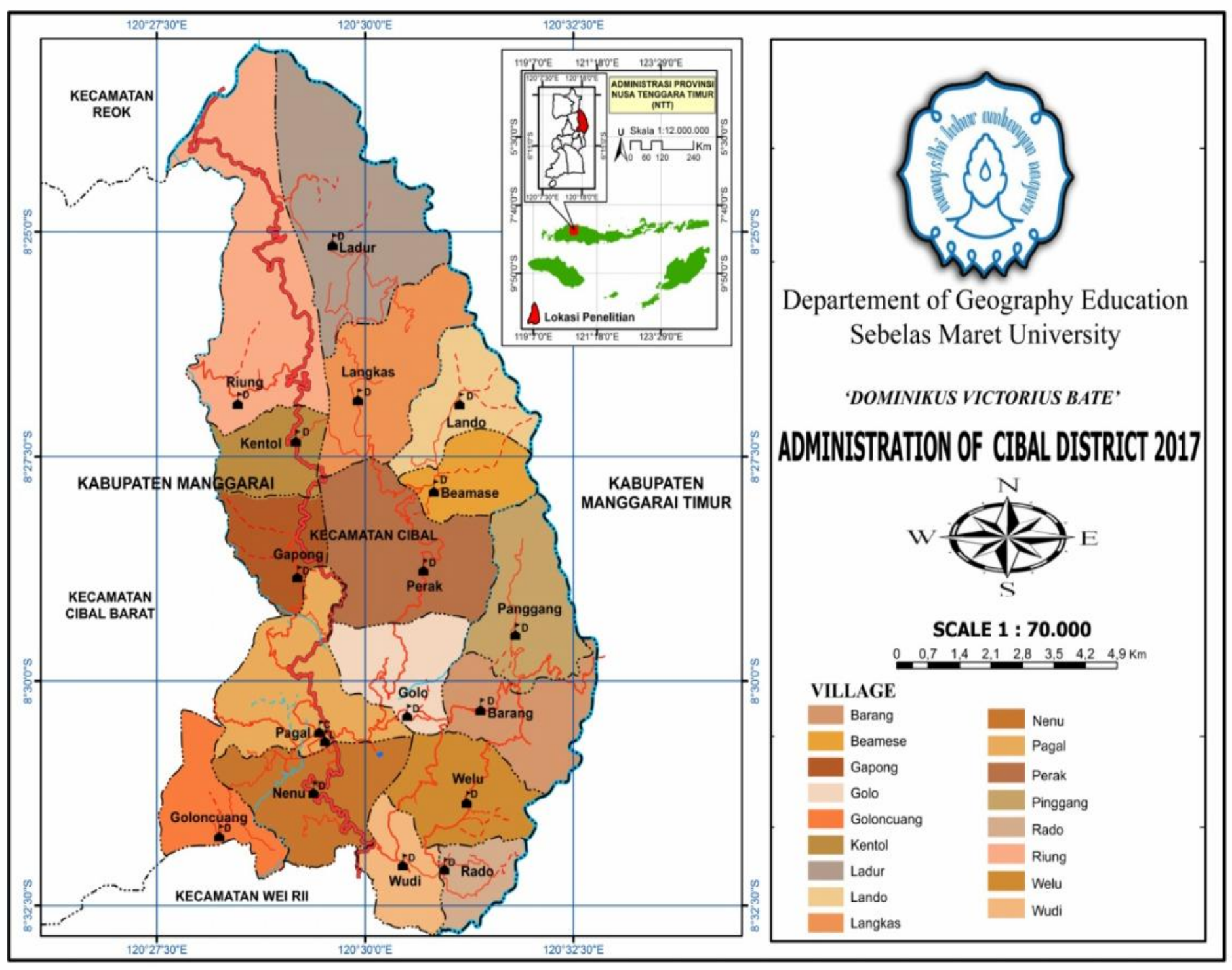

Figure 1: Administration Map of Cibal Districts 2017

The type of this research is qualitative descriptive research. The data used are the primary data in the form of measurement and observation results in the research sites includes population data and settlements (units). While the secondary data in this research is administrative map of Cibal districts, Manggarai Regency.

The sampling technique is saturated side where the member of population as a sample (Sugiyono, 2016). The sample in this research is all sub-districts / village in Cibal Districts of Manggarai Regency. 
The landslide Susceptibility analysis only uses population and settlements. Settlement is the density of settlements in areas that occur landslide. The population is obtained from Cibal District data in 2016 figures.

Population and settlement density data were obtained from the Statistic Central Bureau of Manggarai Regency. Population density and settlements were classified into three classes. They were low, medium, and high class. To know the class interval of population density and settlement, it is used formula:

$$
c=\frac{X-X 1}{\mathrm{k}}
$$

Exp :

$\mathrm{C}=$ Estimation of Class Amount (Low, Medium, high)

$\mathrm{K}=$ Class Amount

$\mathrm{Xn}=$ Highest Value

$\mathrm{X} 1=$ Smallest Value

Source : (Supranto, J, 1996 )

After population density and settlement, the two parameters are classified again into three classes . the classes are low, medium, and high class. To know the class is used calculation in crosstab, as follows :

Table 1. Matrix between Population and settlement Density

\begin{tabular}{cllll}
\hline \multicolumn{2}{l}{ Population Density } & Low & Medium & High \\
\hline & Low & Low & Low & Medium \\
& Medium & Low & Medium & Medium \\
& High & Medium & Medium & High \\
\hline
\end{tabular}

Source : Aditya, Triyas,(2009)

\section{Results and Discussion}

\subsection{Population Density}

The existence of the population is one of the parameters. It is very important in setting the level of susceptibility of landslides because community is a distinguishing factor determining whether the disaster landslide can be categorized as a disaster or just as a natural phenomenon.

Administratively, Cibal districts area is one of area in Manggarai Regency which has a large number of residents. The population in Cibal Districts is 27.482 soul that consist of 13.588 male and 13.894 female population. 
Classification of population density is divided into three categorie. The categories are low, medium and high population density. The calculation is obtained by using the formula:

$$
C=\frac{X-X 1}{\mathrm{k}}
$$

Exp : $\quad \mathrm{C}=$ Approximation of Class

Amount

$\mathrm{k}=\quad$ Class Amount

$\mathrm{Xn}=$ Highest Value

$\mathrm{X} 1=$ Smallest Value

Source : Supranto :1996

From the formula above, it can be obtained the amount of classes are 155 .

Therefore, it can be known the clasification category as follows :

Table 2. Clasification of Population Density Class

\begin{tabular}{lll}
\hline No & & Class of Population Density \\
\hline 1. & $150-305 \mathrm{soul} / \mathrm{km}^{2}$ & Low \\
2. & $305-461 \mathrm{soul} / \mathrm{km}^{2}$ & Medium \\
3. & $461-615 \mathrm{soul} / \mathrm{km}^{2}$ & High \\
\hline
\end{tabular}

For further related of Population Density can be seen on table 4 below :

Table 3. Population Density of Cibal 2017

\begin{tabular}{|c|c|c|c|c|c|}
\hline No & $\begin{array}{c}\text { Sub- } \\
\text { Districts/Village }\end{array}$ & $\begin{array}{c}\text { Population } \\
\text { Amount }\end{array}$ & $\begin{array}{l}\text { Large } \\
\left(\mathbf{k m}^{2}\right)\end{array}$ & $\begin{array}{c}\text { Population } \\
\text { Density } \\
\left(\text { soul/ } / \mathbf{K m}^{2}\right)\end{array}$ & Category \\
\hline 1 & Nenu & 2.452 & 6,95 & 353 & Medium \\
\hline 2 & Wudi & 1.477 & 3,55 & 416 & Medium \\
\hline 3 & Rado & 1.694 & 2,76 & 615 & High \\
\hline 4 & Welu & 2.152 & 5,60 & 384 & Medium \\
\hline 5 & Barang & 1.310 & 5,83 & 225 & Low \\
\hline 6 & Pinggang & 1.452 & 6,58 & 221 & Low \\
\hline 7 & Golo & 1.312 & 5,01 & 262 & Low \\
\hline 8 & Pagal & 2.703 & 8,27 & 327 & Medium \\
\hline 9 & Gapong & 1.095 & 3,97 & 276 & Low \\
\hline 10 & Perak & 1.432 & 9,54 & 150 & Low \\
\hline 11 & Beamese & 1.250 & 3,78 & 331 & Medium \\
\hline 12 & Lando & 990 & 4,85 & 204 & Low \\
\hline 13 & Langkas & 1.416 & 7,90 & 179 & Low \\
\hline 14 & Kentol & 1.081 & 3,90 & 277 & Low \\
\hline 15 & Riung & 2.109 & 13,87 & 152 & Low \\
\hline 16 & Ladur & 1.965 & 12,32 & 160 & Low \\
\hline \multirow[t]{2}{*}{17} & Goloncuang & 1.592 & 4,22 & 377 & Medium \\
\hline & Total & 27.482 & 108,90 & 4.908 & \\
\hline
\end{tabular}

Source : Research Data Analysis 2017 
Based on table 3 above, it can be seen that Cibal has three classes of population density. They are low, medium, and high. There are ten villages that have low population density. The villages in Barang, Pinggang, Golo, Gapong, Perak, Lando, Langkas, Kentol, Riung, and Ladur Village. Six sub-distric/ Villages in Medium category are Nenu Village, Wudi, Welu, Pagal, Beamese, and Goloncuang Village. One Village with high category is Rado Village. Perak Village is the village with the lowest population density of $150 \mathrm{soul} / \mathrm{km}^{2}$ while Rado village is the highest population density of $615 \mathrm{soul} / \mathrm{km}^{2}$. Population density can be seen in the below map:

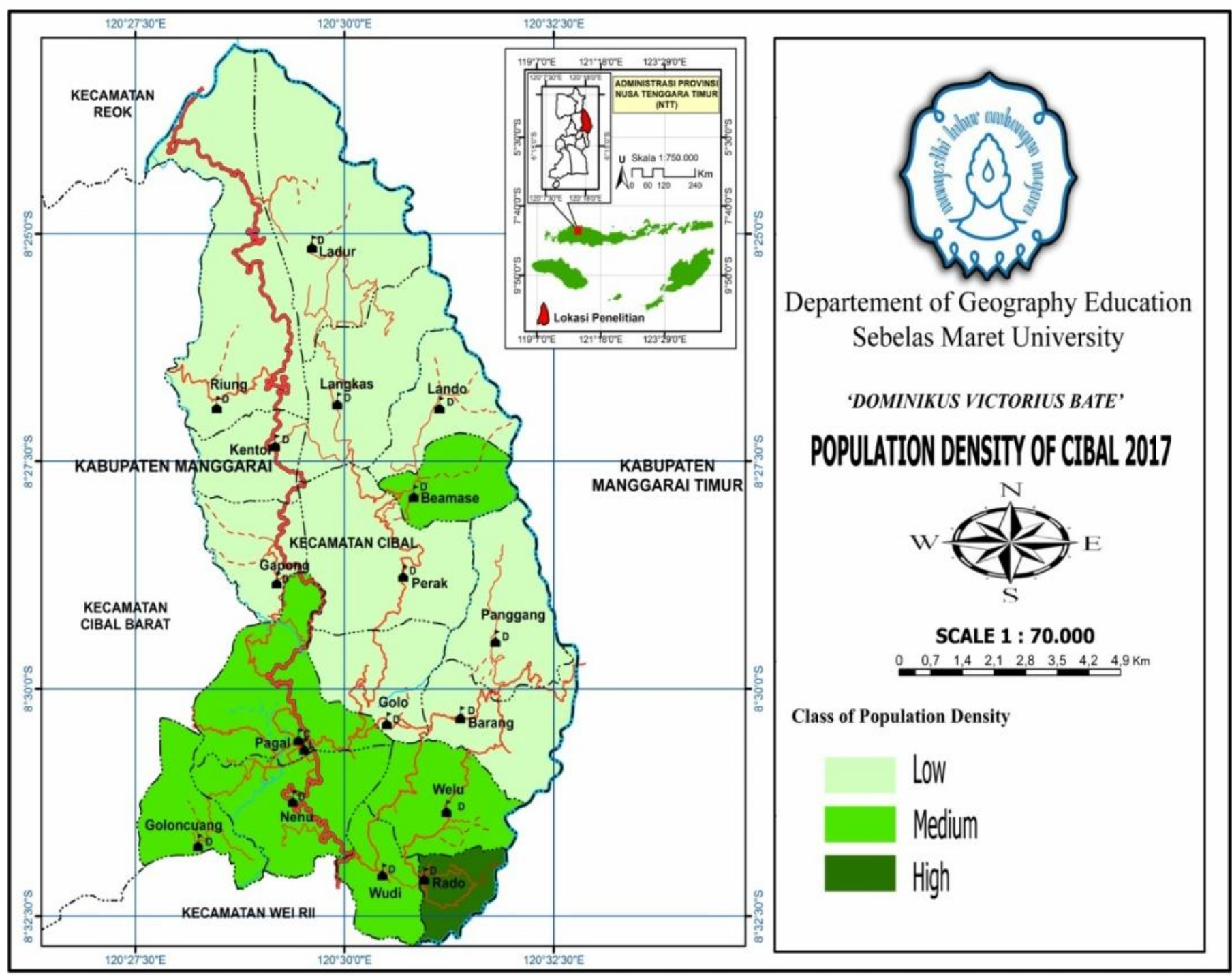

Figure 2 : Population Density Map of Cibal 2017 


\subsection{Settlement Density}

The density of settlements has an effect on the susceptibility of landslide is the addition of load on the land which is in high danger zone so with the addition of this load can potentially the occurrence of landslide. The density of the settlement is the number of houses, schools, and other buildings on a certain land area expressed in units $/ \mathrm{km}^{2}$. Classification of settlement density equal to population density is divided into three categories; low, medium, and high. The calculation of settlement density classification also uses the same formula as population density. From the formula, it can be obtained the number of classes is 19 so it can be known classification category, as follows:

Table 4. Clasification of Settlement Density

\begin{tabular}{ccc}
\hline No & Settlement Density & Class of Settlement Density \\
\hline 1. & $20-39$ Units $/ \mathrm{km}^{2}$ & Low \\
2. & $39-58$ Units $/ \mathrm{km}^{2}$ & Medium \\
3. & $58-76$ Units $/ \mathrm{km}^{2}$ & High \\
\hline
\end{tabular}

For further related to the density of settlements can be seen in table 6 below:

Table 5. Settlement Density of Cibal 2017

\begin{tabular}{clcccc}
\hline No & $\begin{array}{c}\text { Sub- } \\
\text { districts/Village }\end{array}$ & $\begin{array}{c}\text { Settlement } \\
\text { Amount( Unit) }\end{array}$ & $\begin{array}{c}\text { Large } \\
\left(\mathbf{k m}^{2}\right)\end{array}$ & $\begin{array}{c}\text { Settlement Density } \\
\left(\mathbf{U n i t} / \mathbf{K m}^{2}\right)\end{array}$ & Category \\
\hline 1 & Nenu & 430 & 6,95 & 62 & High \\
2 & Wudi & 268 & 3,55 & 76 & High \\
3 & Rado & 184 & 2,76 & 67 & High \\
4 & Welu & 322 & 5,60 & 57 & High \\
5 & Barang & 199 & 5,83 & 34 & Low \\
6 & Pinggang & 265 & 6,58 & 40 & Medium \\
7 & Golo & 225 & 5,01 & 45 & Medium \\
8 & Pagal & 458 & 8,27 & 55 & High \\
9 & Gapong & 236 & 3,97 & 59 & Low \\
10 & Perak & 222 & 9,54 & 23 & Medium \\
11 & Beamese & 208 & 3,78 & 55 & Low \\
12 & Lando & 95 & 4,85 & 20 & Low \\
13 & Langkas & 255 & 7,90 & 32 & Medium \\
14 & Kentol & 192 & 3,90 & 49 & Low \\
15 & Riung & 296 & 13,87 & 21 & Low \\
16 & Ladur & 310 & 12,32 & 25 & High \\
17 & Goloncuang & 318 & 4.22 & 75 & \\
& Total & 4.483 & 108,90 & 797 & \\
\hline
\end{tabular}

Source : Research Data Analysis 2017

Based on table 5, the density of the settlements is classified into three classes. The classesare low, medium, and high. There are six sub-districts / villages with low 
density categories .They are Barang Village, Perak, Lando, Langkas, Riung, and Ladur Village . Five sub-districts / village with medium category that is Pinggang Village, Golo, Pagal, Beamese, and Kentol Village. Six other villages with high category are Nenu Village, Wudi, Rado, Welu, Gapong, and Goloncuang Village. Lando village is the village with the lowest density of settlements .There are 20 units $/ \mathrm{km}^{2}$ while Wudi Village is the village with the highest density of settlements of 76 units $/ \mathrm{km}^{2}$. For more details can be seen on the following map:

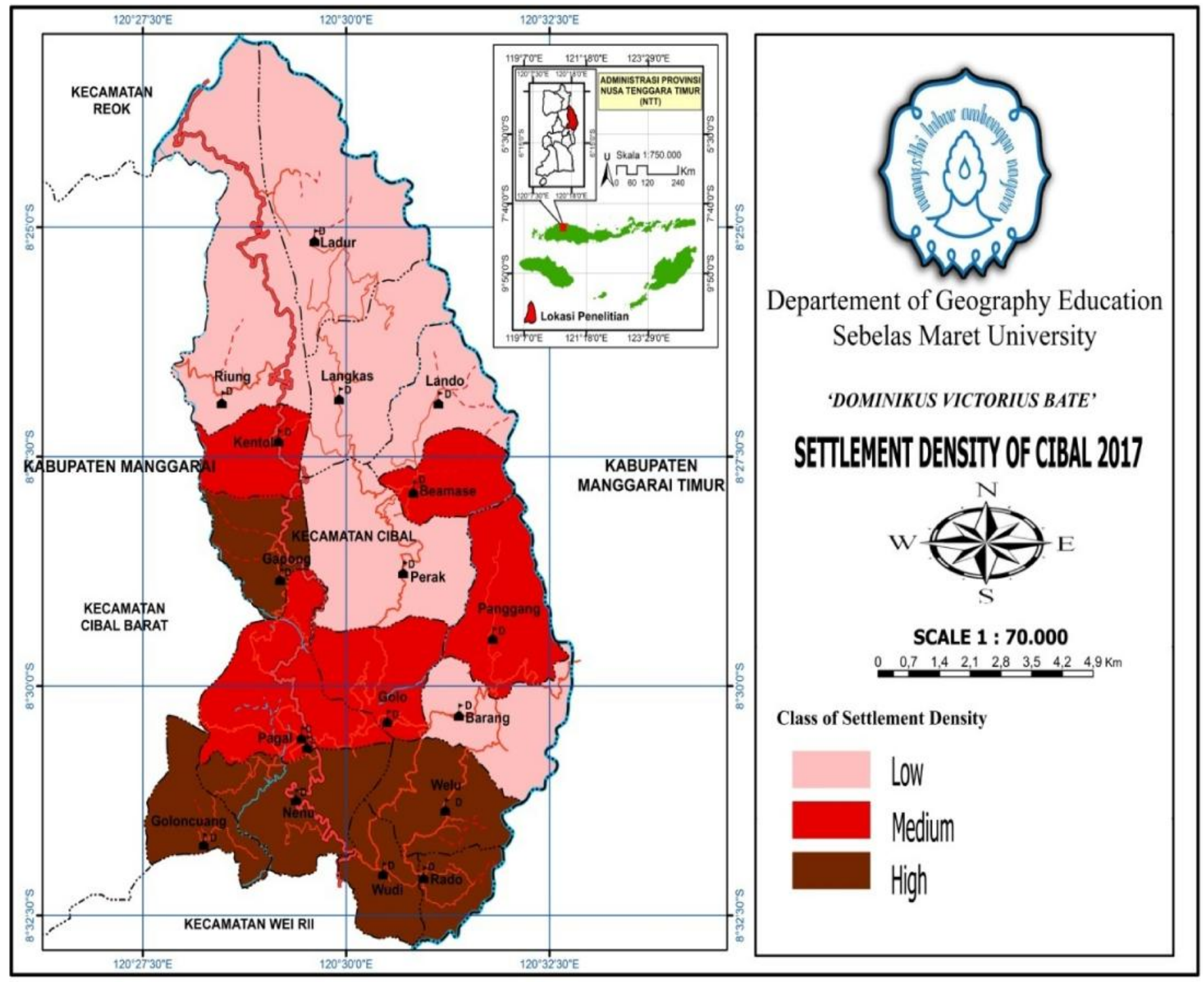

Figure 3 : Settlement Density Map of Cibal 2017 


\subsection{Landslide Susceptibility}

After knowing the condition of population and settlement, so it can be counted density of population and settlement in every Village. The calculation is divided into three classes. The classes Low, Medium, and High class. To search the landslide susceptibility class using Crosstab, it can be seen in table 7 below:

Table 6. Class Count of Landslide Susceptibility Cibal Districts 2017

\begin{tabular}{clccc}
\hline No & Sub-districts/Village & $\begin{array}{c}\text { Population } \\
\text { Density }\end{array}$ & $\begin{array}{c}\text { Setlement } \\
\text { Density }\end{array}$ & $\begin{array}{c}\text { susceptibility of } \\
\text { landslides }\end{array}$ \\
\hline $\mathbf{1}$ & Nenu & Medium & High & Medium \\
$\mathbf{2}$ & Wudi & Medium & High & Medium \\
$\mathbf{3}$ & Rado & High & High & High \\
$\mathbf{4}$ & Welu & Medium & High & Medium \\
$\mathbf{5}$ & Barang & Low & Low & Low \\
$\mathbf{6}$ & Pinggang & Low & Medium & Low \\
$\mathbf{7}$ & Golo & Low & Medium & Low \\
$\mathbf{8}$ & Pagal & Medium & Medium & Medium \\
$\mathbf{9}$ & Gapong & Low & High & Medium \\
$\mathbf{1 0}$ & Perak & Low & Low & Low \\
$\mathbf{1 1}$ & Beamese & Medium & Medium & Medium \\
$\mathbf{1 2}$ & Lando & Low & Low & Low \\
$\mathbf{1 3}$ & Langkas & Low & Low & Low \\
$\mathbf{1 4}$ & Kentol & Low & Medium & Low \\
$\mathbf{1 5}$ & Riung & Low & Low & Low \\
$\mathbf{1 6}$ & Ladur & Low & Low & Low \\
$\mathbf{1 7}$ & Goloncuang & Medium & High & Medium \\
\hline
\end{tabular}

Source : Data Analysis 2017

Based on the calculation of the class of population density and the density of settlements, it can be obtained level of susceptibility landslide in each Sub-districts or village in Districts Cibal Manggarai Regency. For the class of susceptibility is divided into three classes namely low, medium, and high landslide susceptibility classes. As for explanation of each class of landslide susceptibility, as follows:

\section{a. Low Landslide susceptibility level (L)}

Areas with low landslide susceptibility have little or no impact on landslides. The relatively small population and settlement density makes the area relatively vulnerable. Population density in this area ranges from 150 - $305 \mathrm{soul} / \mathrm{km}^{2}$ while the density of settlements ranges from 20 to 39 units $/ \mathrm{km}^{2}$. Low landslide susceptibility rates are found in village Barang, Pinggang, Golo, Perak, Lando, Langkas, Kentol, Riung, and Ladur. 
Low landslide susceptibility can occur due to low population densities and clasified settlements. The area of low landslide susceptibility is $6.979,65$ hectares or $64,09 \%$ of the total area.

\section{b. Medium Landslide susceptibility level (M)}

Areas that has medium susceptibility landslides are having moderate effects on landslides. The medium of Population density and settlements that are making the area relatively has medium susceptibility. Population density in this area ranges from 305 $461 \mathrm{soul} / \mathrm{km}^{2}$ while the density of settlements ranges from 39 to 58 units $/ \mathrm{km}^{2}$. The level of landslide susceptibility in Pagal, Nenu, Wudi, Welu, Gapong, Beamese and Goloncuang villages. The area of moderate avalanche susceptibility is $3.634,67$ hectares or $33,38 \%$ of the total area.

\section{c. High landslide susceptibility level (H)}

Areas with high landslide susceptibility have a high or large influence on landslides. Population density and high settlement make the area classified as having high susceptibility. Population density in this area ranges from $461-615 \mathrm{soul} / \mathrm{km}^{2}$ while the density of settlements ranges from 58 to 76 units $/ \mathrm{km}^{2}$. The high landslide susceptibility rate is found only in Rado Village. The high landslide susceptibility area is 275,65 hectares or $2,35 \%$ of the total area of Cibal Districts.

Based on the analysis of landslide susceptibility level, the distribution can be seen on the map below: 


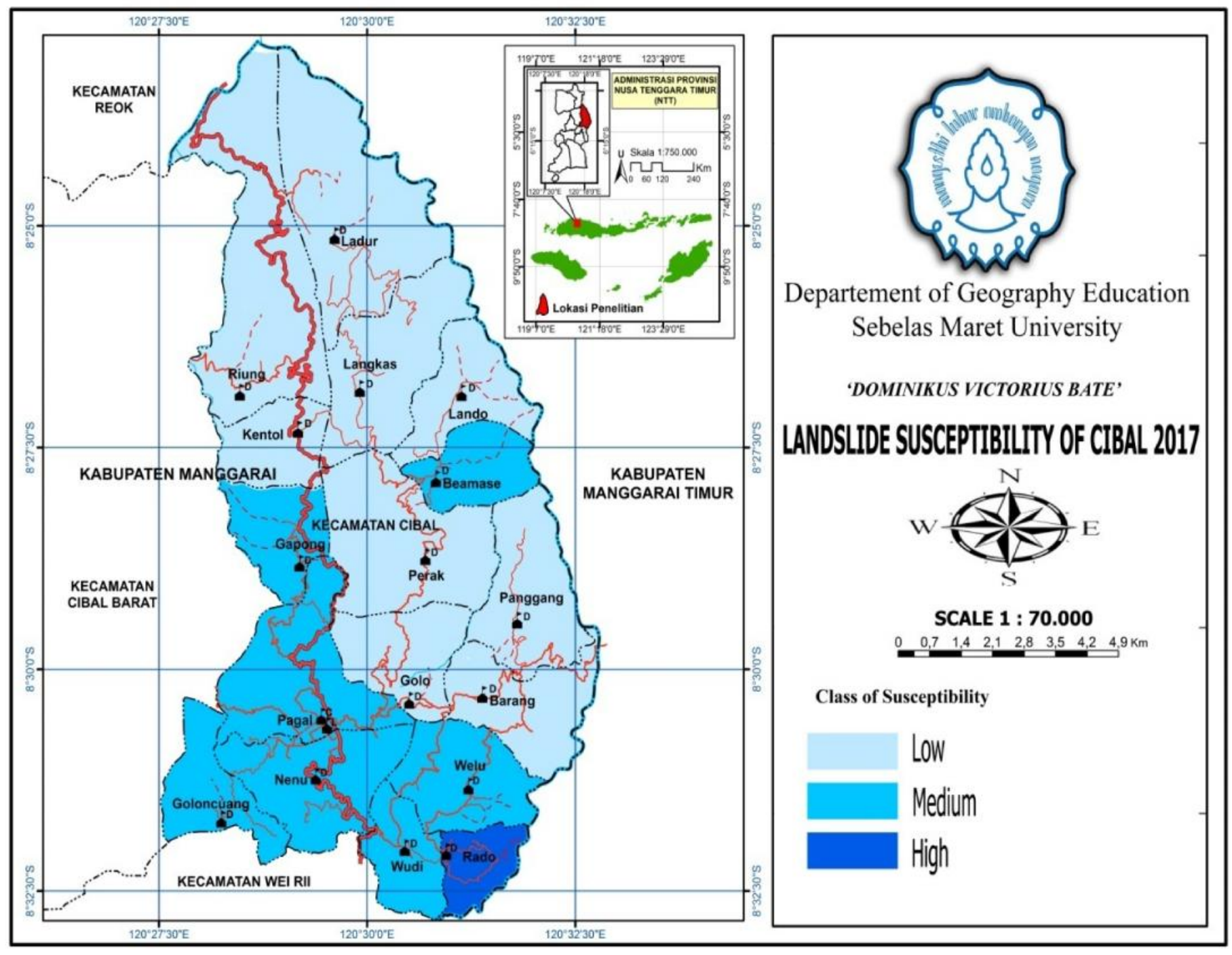

Figure 4 : Landslide Susceptibility Map of Cibal 2017

\section{Conclusion}

Based on the results of this research, it can be concluded that the susceptibility of landslide in Cibal Districts , Manggarai Regency of 2017. There are three classes of susceptibility, low, medium, and high. The low landslide susceptibility was found in Barang Village, Golo Village, Pinggang Village, Perak Village, Lando Village, Langkas Village, Kentol Village, Riung Village, and Ladur Village with $6.979,65$ hectares or $64,09 \%$, the susceptibility level of landslide is located in Nenu Village, Wudi Village, Welu Village, Pagal Village, Gapong Village, Beamese Village, and Golo Ncuang Village with an area of 
$3.634,67$ hectares or $33,38 \%$. While the high landslide susceptibility rate only found in Rado

Village with an area of 275,65 hectares or $2,35 \%$ of the total area of Cibal Districts.

\section{References}

Aditya, Triyas \& Marjuki, Bramantyo, (2009) Preparation of DIY Province Risk Map. Yogyakarta: Provincial Government of DIY \& PPMU SCDRR

Regional Disaster Mitigation Agency (BPBD) of Manggarai Regency in 2017

Nurjanah. 2012. Disaster Management. Bandung: Alfabeta

Regulation of National Agency for Disaster Management 04 of 2008 on guidelines for the preparation of disaster management

Ministry of Public Works Regulation No. 22 of 2007

Muta'ali. 2012. Environmental Support Capacity for Regional Development Planning. Yogyakarta: Faculty of Geography Gadjah Madah Univercity .

Gems, S. 2016. Risk Management And Landslide Mitigation. UGM: Yogyakarta

Sugiyono. 2016. Quantitative Research Methods, Qualitative, And R \& D. Bandung: Alfabeta

Supretno, J. (1996). Statistics, Theory and Applications. Jakarta: Erlangga

Suripin.2002. Preservation of Land and Water Resources.Yogyakarta. 